\title{
Genetic Analysis of SNPs in GH, GHR, IGF-I and IGFBPII Genes and their Association with Some Productive and Reproductive Traits in Native Breeder Hens
}

\author{
Hamed Kazemi ${ }^{1}$, Mohammad Rezaei ${ }^{2}$, Hasan Hafezian ${ }^{2}$, Ghodrat Rahimi Mianji², and Mojtaba Najafi ${ }^{2 *}$ \\ ${ }^{1}$ Department of Agricultural and Food Sciences, University of Bologna, Bologna, Italy \\ ${ }^{2}$ Faculty of Animal Sciences and Fisheries, Sari Agricultural Sciences and Natural Resources University, Sari, Iran
}

\begin{abstract}
The aim was to study the polymorphisms in GH, GHR, IGF-I and IGFBPII genes and their association with productive and reproductive traits. DNA was extracted from blood samples of 380 breeder hens of Mazandaran native fowls breeding station by modified salting out method. For genotyping, PCR products of GH, GHR, IGF-I and IGFBPII loci were digested with specific restriction enzymes. We found six genotypes of $A A, B B, C C, A B, A C$ and $B C$ with the frequency of $0.10,0.01,0.36,0.07,0.34$ and 0.12 in $G H$, two haploid alleles and genotypes of $\mathrm{B}+$ and $\mathrm{B}$ - with the frequency of 0.72 and 0.28 in $G H R$, three genotypes of $\mathrm{BB}, \mathrm{Bb}$, bb with the frequency of $0.49,0.44$ and 0.07 in IGF-I and three genotypes of CC, CT and TT with the frequency of $0.14,0.62$ and 0.24 in IGFBPII loci, respectively. Significant associations were found between SNPs in IGF-I locus and egg number at 120-270 and 345-375 days of age, egg weight at puberty and percentage of hatchability traits $(P<0.05)$. We also found significant effects of $G H R$ and IGFBPII loci on egg number at 345-375 days of age and average egg weight at 345-375 days of age traits, respectively $(\mathrm{P}<0.05)$. Mean comparisons analysis between different genotypes of $\mathrm{GH}$ gene for body weight at day one and puberty, age at sexual maturity, egg weight at puberty and 30 weeks of age, average egg weight and egg number at 345-375 days of age and also percentage of fertility traits and IGFBPII genotypes for laying intensity trait were observed to be significant $(\mathrm{P}<0.05)$. Regarding the significant effects of $G H R$, IGF-I and IGFBPII genes on egg production traits, it could be resulted that these candidate genes may be used as the candidate markers in poultry breeding programs to improve productive and reproductive traits in this population.
\end{abstract}

Keywords: Polymorphism; GH; GHR; IGF-I; IGFBPII; Mazandaran native fowls; PCR-RFLP

\section{Introduction}

Poultry industry occupies a prominent position as a major source of animal protein supply for human consumptions and over the years, the growth of poultry industry has followed a pattern closely dictated by the economic fortunes of the countries. Poultry is key in genetic researches due to breeding feasibility, relatively short generation interval and distinct phenotypes. Improving economic traits in chicken has increasingly become of interest and the identification and utilization of QTLs provide the potential for genetic improvement in selection programs without slaughtering. Recent advances in molecular genetics have led to the discovery of genes, or markers associated with genes that affect meat quality [1]. Applying a candidate gene may result in higher efficiency to detect desired economic traits necessary to increase production and reproduction performances in poultry breeding programs. The growth-correlated genes especially GH and IGF-I genes are regarded as the most promising candidate genes for growth performance and carcass quality traits in chickens [2], necessitating comprehensive genetic probes into the genes responsible for growth and production and evaluating their genetic polymorphisms more accurately.

\section{Growth hormone}

The growth hormone $(\mathrm{GH})$ is responsible for many metabolic pathways such as growth, reproduction, puberty, and immune responses and organizes these functions in cells through its receptor [3]. The chicken growth hormone gene $(\mathrm{cGH})$ is located on the chromosome 1 with the length of 4098 bp containing 5 exons and 4 introns [4]. The significant effect of this hormone on laying in chickens has been reported by increasing the number of small follicles in the ovary and also improving the thickness of egg shell [5]. Association study of $\mathrm{GH}$ gene polymorphisms and its importance has been confirmed in several studies due to finding significant associations between SNPs and different traits in chickens including body and drumstick weight at 6 weeks of age [6], sexual maturity, egg number and body weight [7], body weight at $4,6,8$, and 10 weeks of age as well as daily weight gain [2], and also physiological traits including triglyceride content and total serum protein in broiler chickens [8].

\section{Growth hormone receptor}

The growth hormone receptor gene (GHR) is a member of type 1 cytokine superfamily with a molecular weight of 71500 Dalton and codes a protein with 638 amino acids as the membrane receptor for $\mathrm{GH}$. The chicken growth hormone receptor gene (cGHR) has 10 exons and 9 intron located on the chromosome $\mathrm{Z}$ [9]. GH binding to its receptor activates intracellular and extracellular metabolic reactions. This gene along with the system GH-IGF-I regulates follicles in animals that are in their fast-growing phase [10]. GHR gene is perceived as one of the most likely candidate genes for reproductive traits as well as egg production and egg shell quality traits in poultry through its significant effects on double-yolk eggs production [11], egg shell thickness [12], and also live body weight [13], and subcutaneous fat thickness [14].

*Corresponding author: Mojtaba Najafi, Faculty of Animal Sciences and Fisheries, Sari Agricultural Sciences and Natural Resources University, Km 9th Farah-Abad road, Khazar square, Sari, Iran, Tel: +989132625020; E-mail: mojtaba_najafy@yahoo.com

Received April 10, 2018; Accepted April 24, 2018; Published April 30, 2018

Citation: Kazemi H, Rezaei M, Hafezian H, Mianji GR, Najafi M (2018) Genetic Analysis of SNPs in GH, GHR, IGF-I and IGFBPII Genes and their Association with Some Productive and Reproductive Traits in Native Breeder Hens. Gene Technol 7: 145. doi: 10.4172/2329-6682.1000145

Copyright: $\odot 2018$ Kazemi H, et al. This is an open-access article distributed under the terms of the Creative Commons Attribution License, which permits unrestricted use, distribution, and reproduction in any medium, provided the original author and source are credited. 


\section{The insulin-like growth factor I}

The insulin-like growth factor I gene (IGF-I) is located on chromosome 1 and has 4 exons and 3 introns in chickens. The size of this gene is $50 \mathrm{kbp}$ which codes a single chain peptide with 70 amino acids [15]. The IGF-I gene may play an eminent role in the growth of various tissues including muscle cells, cartilage and bone [16]. Many researches carried out in chickens have revealed this gene's significant effects on regulating egg production, egg weight and ovarian growth [17], total egg number at the first 12 weeks after sexual maturity [18], body weight at 2, 4, and 6 weeks of age and average daily weight gain [2], body weight at 4 to 20 weeks of age [19], and egg production at 300 and 400 days of age as well as average mean laying days [12]. Researchers also identified SNPs including (C/A) in promoter region [20], and (G/A) in intron 3 [21] of IGF-I gene, that were significantly related to chest muscle weight and body weight, hematocrit and abdominal fat percentages in chickens, respectively.

\section{The insulin-like growth factor binding protein II}

The insulin-like growth factor binding protein II gene (IGFBPII) has the size of approximately $38 \mathrm{kbp}$ that is located on chromosome 7 , entailing four short exons and three long introns and also contains 275 amino acids [22]. In indigenous and commercial chicken populations, significant associations of this gene were reported with body weight at the time of hatch and days $7,14,21$, and 28 of age [22], growth rate at 4-8 and 8-12 weeks of age in hens and 0-4 weeks of age in rosters [23], and body weight at the time of hatch and 12 weeks of age [24]. Moreover, some SNPs have been detected to have significant effect on growth traits in indigenous chickens such as a SNP $(\mathrm{C} / \mathrm{T})$ in intron 2 on body weight at 2-12 weeks of age, length and weight of metatartos, shank, femur regions and abdominal fat weight [25], and also a SNP $(1196 \mathrm{C} \rightarrow \mathrm{A})$ in 3 '-flanking region on abdominal fat mass and its percentage [26].

Considering the pivotal roles of these candidate genes in poultry production, the importance of the conservation and genetic improvement of native chicken populations and lack of a comprehensive study in this case in Mazandaran native fowls, the present study was conducted to investigate the polymorphisms of GH, GHR, IGF-I and IGFBPII loci and their association with some productive and reproductive traits in breeder hens of Mazandaran native fowls breeding station.

\section{Materials and Methods}

\section{Experimental population}

The Mazandaran Native Fowl breeding station was established in 1988 with the aim of preserving the population of endangered native fowls. The activity of this research includes reproduction and genetic enhancement of this native population. All native fowls had been grown in the same condition. The productive and reproductive traits included body weight (BW) at day one, 8 and 12 weeks of age and puberty, age of sexual maturity (ASM), egg number (EN) at 120-270 and 345-375 days of age, laying intensity (LI), egg weight (EW) at puberty, average egg weight (AEW) at 28, 30 and 32 weeks of age and 345-375 days of age, percentage of fertility $(\mathrm{PF})$ and percentage of hatchability $(\mathrm{PH})$ were recorded and measured accurately by researchers.

\section{DNA extraction and amplification of gene fragments}

A total of 380 blood samples were collected from selected native breeder fowls. DNA was extracted through modified salting-out method. In order to amplify all these loci, PCR reactions were prepared with the volume of $25 \mu \mathrm{l}$ as follow: $2.5 \mu \mathrm{l}$ of PCR buffer, $0.5 \mu \mathrm{l}$ of each primer, $1.5 \mu \mathrm{l}$ of genomic DNA, $0.5 \mu \mathrm{l}$ of dNTP, $0.65 \mu \mathrm{l}$ of $\mathrm{MgCl}_{2}, 0.2$ $\mu \mathrm{l}(500 \mathrm{U})$ of Taq Polymerase and $17.65 \mu \mathrm{l}$ of distilled water. Initial denaturation and final extension were performed at $95^{\circ} \mathrm{C}$ for 240 seconds and $72^{\circ} \mathrm{C}$ for 300 seconds, respectively (Table 1 ).

\section{Genotyping}

In this study, $5 \mu \mathrm{l}$ of the PCR product of GH, GHR, IGF-I and IGFBPII genes were digested with $0.3 \mu \mathrm{l}$ of restriction enzymes at $37^{\circ} \mathrm{C}$ for 12 hours, respectively. Obtained products were segregated by agarose gel electrophoresis $(2.5 \%)$. Then, the gel was stained with Ethidium bromide and the fragments were observed using Gel-doc machine.

\section{Statistical analysis}

To verify the equilibrium of the genotypic frequencies with the Hardy-Weinberg Equilibrium (HWE), Chi-square test $\left(\mathrm{X}^{2}\right)$ was used. Gene frequencies calculation and statistical analyzes were performed using SAS 9.1 software. The effects of GH, GHR, IGF-I and IGFBPII genes on the studied traits were evaluated with GLM procedure.

\section{Results}

\section{Amplification of the gene fragments}

All fragments were amplified using specific primers. All amplified fragments had strong bands, with no extra band or dimmer (Figure 1).

\section{Allelic and genotypic frequencies}

For genotyping all samples, RFLP technique was used. The polymorphism of GH gene was detected by digestion of PCR products using MspI restriction enzyme [27], and three alleles of A, B and C and 6 different genotype profiles were observed in intron 1 (Figure 2 ). These six profiles were shown with allele $A$ or AA genotype containing the fragments of $414 \mathrm{bp}, 237 \mathrm{bp}$ and $147 \mathrm{bp}$, allele B or BB genotype containing the fragments of $267 \mathrm{bp}, 237 \mathrm{bp}, 147 \mathrm{bp}$ and 125 $\mathrm{bp}$, allele $\mathrm{C}$ or CC genotype including two fragments of $539 \mathrm{bp}$ and $237 \mathrm{bp}$ and profiles 4 to 6 entailing $\mathrm{AB}, \mathrm{AC}$ and $\mathrm{BC}$ genotypes that were heterozygous of the $\mathrm{A}, \mathrm{B}$ and $\mathrm{C}$ alleles. The polymorphism of the GHR gene was demonstrated by digestion of PCR products using NspI restriction enzyme with only one restriction site (Figure 2). Two alleles and two haploid genotypes of $\mathrm{B}+$ and $\mathrm{B}$ - were detected. The $\mathrm{B}+$ allele

\begin{tabular}{|c|c|c|c|c|c|}
\hline Gene & Primer sequence & Enzyme & Region & Annealing & Reference \\
\hline $\mathrm{GH}$ & $\begin{array}{l}\text { F: 5'- ATCCCCAGGCAAACATCCTC -3' } \\
\text { R: 5'- CCTCGACATCCAGCTCACAT -3' }\end{array}$ & Mspl & Intron 1 & $69^{\circ} \mathrm{C}$ & [27] \\
\hline GHR & $\begin{array}{l}\text { F: 5'- ACGAAAAGTGTTTCAGTGTTGA -3' } \\
\text { R: 5'- TTTATCCCGTGTTCTCTTGACA -3' }\end{array}$ & Nspl & Intron 5 & $56^{\circ} \mathrm{C}$ & [12] \\
\hline IGF-I & $\begin{array}{l}\text { F: 5'- GACTATACAGAAAGAACCAC -3 } \\
\text { R: 5'- TATCACTCAAGTGGCTCAAGT -3' }\end{array}$ & Pstl & 5'-UTR & $56^{\circ} \mathrm{C}$ & [26] \\
\hline IGFBPII & $\begin{array}{l}\text { F: 5'- TTTGGTTGAGTCCTAGGCTTG -3' } \\
\text { R: 5'- GGCGTACTACACTGCAGAGG -3' }\end{array}$ & Eco72I & Intron 2 & $60^{\circ} \mathrm{C}$ & {$[25]$} \\
\hline
\end{tabular}

Table 1: Primer sequence and other specific information for each genetic locus. 
Citation: Kazemi H, Rezaei M, Hafezian H, Mianji GR, Najafi M (2018) Genetic Analysis of SNPs in GH, GHR, IGF-I and IGFBPII Genes and their Association with Some Productive and Reproductive Traits in Native Breeder Hens. Gene Technol 7: 145. doi: 10.4172/2329-6682.1000145

Page 3 of 7

consisted of two fragments of $540 \mathrm{bp}$ and $200 \mathrm{bp}$ and a $740 \mathrm{bp}$ fragment for the B- allele [12]. Since the GHR gene in chickens is located on the Z chromosome, the genotype of this locus is haploid. The polymorphism of the IGF-I gene was detected by digestion of PCR products using PstI restriction enzyme [28], resulted in two alleles of $B$ and $b$ and three genotypes of $\mathrm{Bb}$ including a $621 \mathrm{bp}$ fragment (without any cutting), $\mathrm{Bb}$ consisted of three fragments of 621,364 , and $257 \mathrm{bp}$, and bb containing two fragments of 364 and 257 bp (Figure 3). The polymorphism of the IGFBPII gene was also detected by digestion of PCR products using Eco72I restriction enzyme [22], and two alleles of $\mathrm{C}$ and $\mathrm{T}$ and subsequently three genotypes of CC entailing two fragments of 477 and $50 \mathrm{bp}$ (Table 2), CT containing three fragments of $527 \mathrm{bp}, 477 \mathrm{bp}$ and $50 \mathrm{bp}$ and TT with a $527 \mathrm{bp}$ fragment (without any cutting) were obtained (Figure 3).
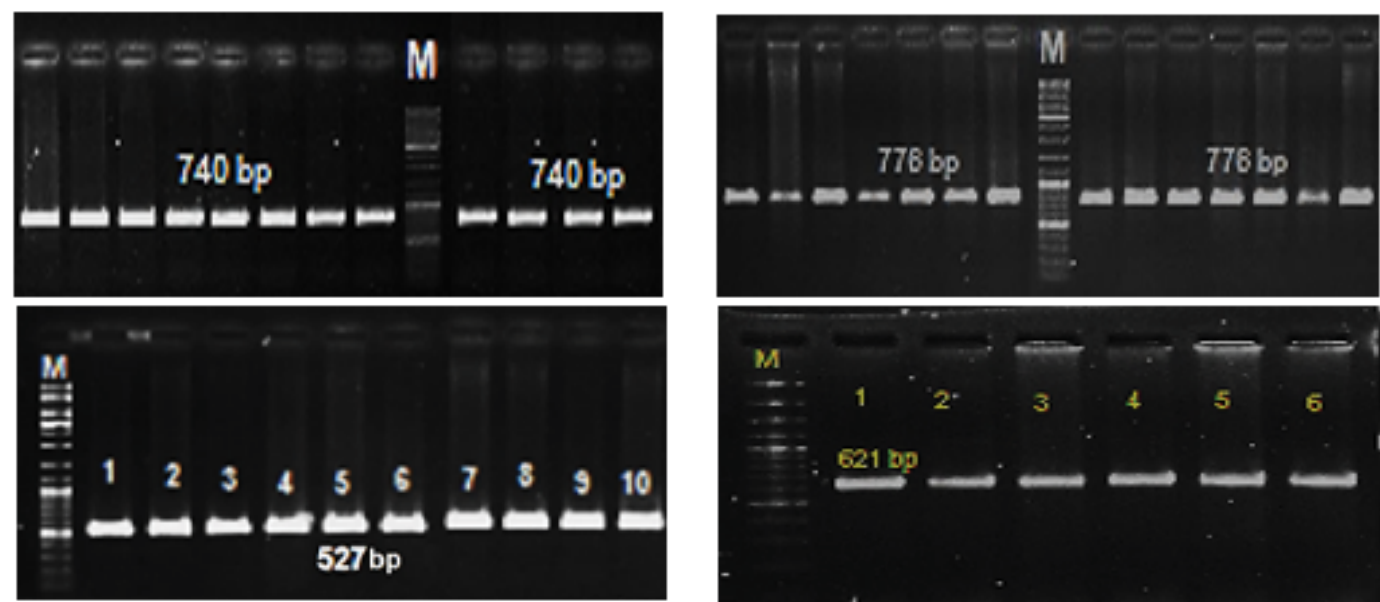

Figure 1: PCR products of GH (intron 5, 776 bp), GHR (intron 5, 740 bp), IGF-I (5'-UTR, 621 bp) and IGFBPII (intron 2, 527 bp) genes
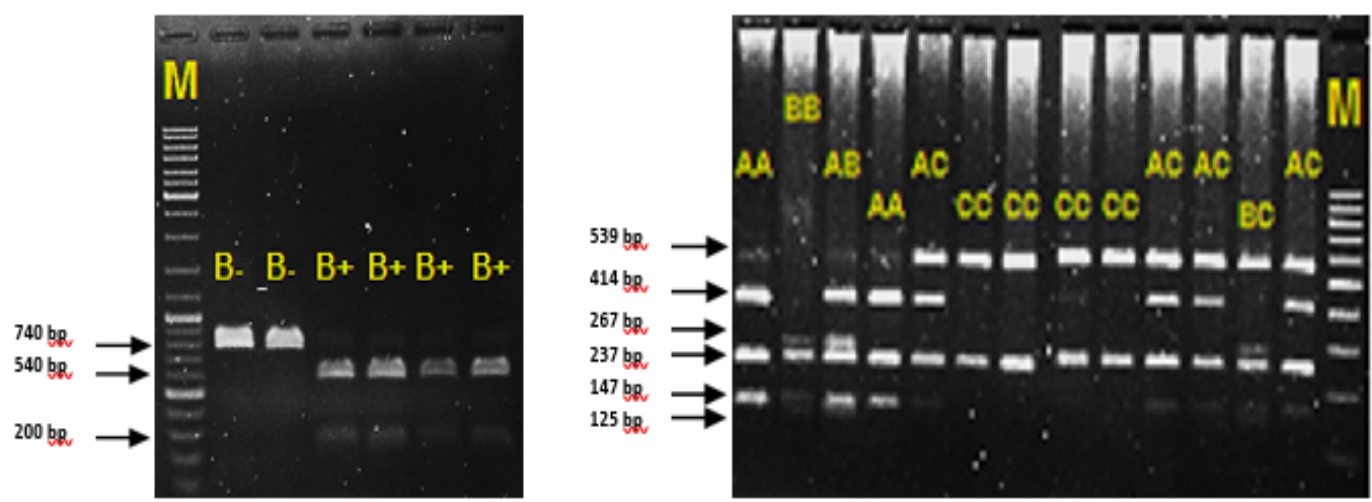

Figure 2: RFLP pattern and different genotypes of GH (right) and GHR (left) loci.
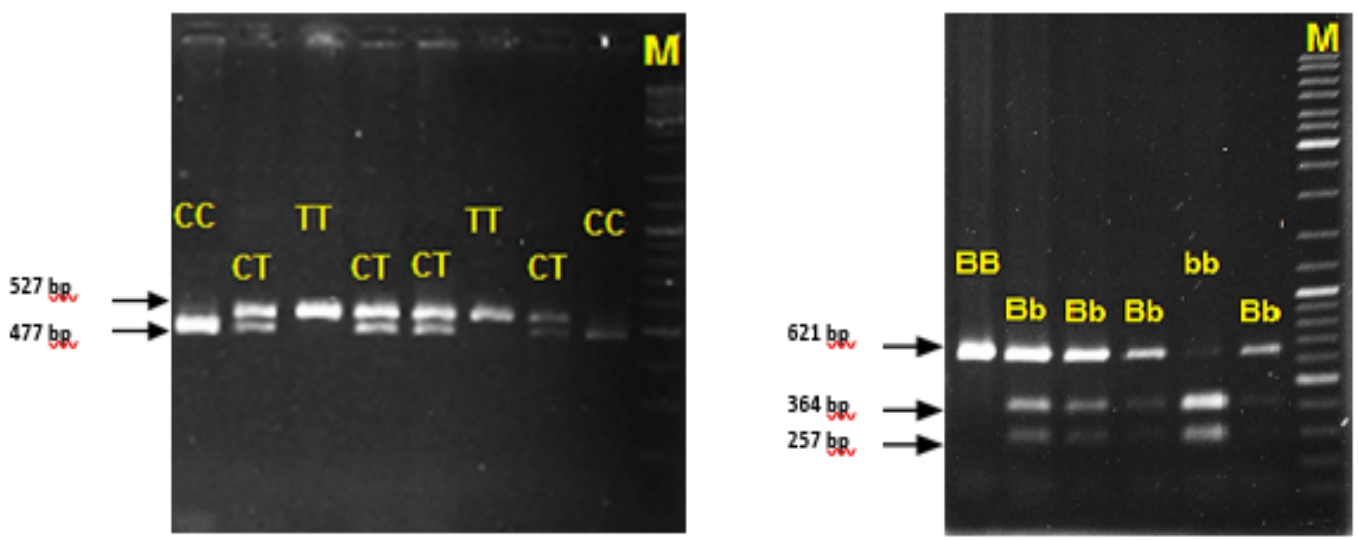

Figure 3: RFLP pattern and different genotypes of IGF-I (right) and IGFBPII (left) loci. 
Citation: Kazemi H, Rezaei M, Hafezian H, Mianji GR, Najafi M (2018) Genetic Analysis of SNPs in GH, GHR, IGF-I and IGFBPII Genes and their Association with Some Productive and Reproductive Traits in Native Breeder Hens. Gene Technol 7: 145. doi: 10.4172/2329-6682.1000145

Page 4 of 7

\section{Association analysis}

Investigation of the association between genotypic patterns in these gene loci with the studied traits in native breeder fowls population including body weight related traits (BW at day one, 8 and 12 weeks of age and puberty), egg production related traits (EN at 120-270 and $345-375$ days of age, LI, EW at puberty, AEW at 28, 30 and 32 weeks of age, and at 375-345 days of age) and reproductive traits (ASM, PF and $\mathrm{PH}$ ) showed that there were significant correlations between $G H R$, $I G F-I$ and IGFBPII genes polymorphisms and some traits. In GHR locus, a significant association was found between SNP and EN at 375345 days of age trait. There were also significant effects of IGF-I gene on EN at 120-270 and 345-375 days of age, EW at puberty and PH traits and in IGFBPII gene on AEW at 345-375 days of age trait (Table 3). Mean comparison analysis results demonstrated significant differences between different genotypes of GH gene in BW (at day one and puberty), EW (at puberty and 30 weeks of age), ASM, EN and AEW at 345-375 days of age, and PF and also genotypes of IGFBPII gene in the LI trait (Tables 3 and 4). Regarding the results of association analysis between the SNPs and the studied traits and also the mean comparison analysis between genotypes, it was determined that the breeder hens with B- (in GHR gene), bb (in IGF-I gene) and CT (in IGFBPII gene) genotypes could be used as suitable parents for the next generation in order to increase egg production as well as improve percentage of hatchability in this population. Also, the hens with $\mathrm{Bb}$ genotypes were more competent than bb genotype (in IGF-I gene) to be considered as the next generation's parents if the breeding objective is producing egg with higher weight. Furthermore, in $\mathrm{GH}$ gene, the positive effect of $\mathrm{C}$ allele on BW related traits was determined and $\mathrm{AC}, \mathrm{BC}$ and $\mathrm{CC}$ genotypes had the highest performances. On the other hand, AA, AC and CC genotypes were associated with the highest records in EN and AEW traits, which indicates the simultaneous and influential effects of $\mathrm{A}$ and $\mathrm{C}$ alleles in this genetic locus and for these traits. As a result, breeder hens with $\mathrm{AC}$ and $\mathrm{CC}$ genotypes could also be regarded as the next generation's parents for improving EN, AEW and BW traits.

\section{Discussion}

Most of the economic traits in livestock production demonstrate continuous variation, although their underlying genetic nature is very complex. Because of the presence of neutral polymorphisms that have spread throughout the genome, it is possible to find chromosomal areas including genes that affect these traits [12]. Currently, it has increasingly been considered in research to probe into balanced

\begin{tabular}{|c|c|c|c|c|c|c|c|c|c|}
\hline \multirow{3}{*}{$\begin{array}{c}\text { Gene } \\
\mathrm{GH}\end{array}$} & \multicolumn{5}{|c|}{ Allelic frequency } & \multicolumn{4}{|c|}{ Genotypic frequency } \\
\hline & A & B & C & AA & BB & CC & $A B$ & AC & $\mathrm{BC}$ \\
\hline & 0.305 & 0.098 & 0.597 & 0.10 & 0.01 & 0.36 & 0.07 & 0.34 & 0.12 \\
\hline \multirow{2}{*}{ GHR } & $\mathrm{B}+$ & B- & -- & $\mathrm{B}+$ & B- & -- & -- & -- & -- \\
\hline & 0.72 & 0.28 & -- & 0.72 & 0.28 & -- & -- & -- & -- \\
\hline \multirow{2}{*}{ IGF-I } & B & b & -- & BB & $\mathbf{B b}$ & bb & -- & -- & -- \\
\hline & 0.71 & 0.29 & -- & 0.47 & 0.43 & 0.10 & -- & -- & -- \\
\hline \multirow{2}{*}{ IGFBPII } & C & $T$ & -- & CC & CT & $\mathrm{TT}$ & -- & -- & -- \\
\hline & 0.44 & 0.56 & -- & 0.14 & 0.62 & 0.24 & -- & -- & -- \\
\hline
\end{tabular}

Table 2: Allelic and genotypic frequencies of GH, GHR, IGF-I and IGFBPII loci.

\begin{tabular}{|c|c|c|c|c|c|}
\hline Gene & Traits & \multicolumn{3}{|c|}{ Genotypes and Means } & \multirow{2}{*}{ p-value } \\
\hline \multirow{5}{*}{ IGF-I } & -- & BB & $\mathrm{Bb}$ & bb & \\
\hline & $\mathrm{EN}^{1}$ & $50 \pm 1.11^{b}$ & $50 \pm 1.13^{b}$ & $57 \pm 3.30^{\mathrm{a}}$ & $0.0463^{* *}$ \\
\hline & $\mathrm{EN}^{2}$ & $14 \pm 0.51^{b}$ & $16 \pm 0.52^{\mathrm{a}}$ & $16 \pm 0.70^{a}$ & $0.0230^{* *}$ \\
\hline & $\mathrm{EW}^{\mathrm{P}}$ & $38.72 \pm 0.64^{\mathrm{ab}}$ & $40.30 \pm 0.66^{a}$ & $36.76 \pm 1.67^{\mathrm{b}}$ & $0.0446^{* *}$ \\
\hline & $\mathrm{PH}$ & $54.29 \pm 3.18^{\mathrm{b}}$ & $57.91 \pm 3.20^{b}$ & $73.23 \pm 7.58^{a}$ & $0.0501^{*}$ \\
\hline \multirow{2}{*}{ GHR } & -- & B+ & B- & -- & -- \\
\hline & $\mathrm{EN}^{2}$ & $16 \pm 0.52^{b}$ & $18 \pm 0.65^{a}$ & -- & $0.0193^{* *}$ \\
\hline \multirow{3}{*}{ IGFBPII } & -- & CC & CT & TT & -- \\
\hline & $\mathrm{AEW}^{\mathrm{H}}$ & $58.04 \pm 0.80^{\mathrm{ab}}$ & $59.58 \pm 0.44^{a}$ & $56.94 \pm 0.66^{b}$ & $0.0464^{* *}$ \\
\hline & $\mathrm{LI}$ & $67.42 \pm 2.22^{\mathrm{ab}}$ & $68.77 \pm 1.16^{a}$ & $64.69 \pm 1.70^{b}$ & $0.0707^{\mathrm{ns}}$ \\
\hline
\end{tabular}

ns: Non-Significant, ${ }^{* *} \mathrm{P}<0.05,{ }^{*} \mathrm{P} \leq 0.05, \mathrm{EN}^{1}$ : EN at $120-270$ days of age, EN ${ }^{2}$ : EN at $345-375$ days of age, EW $\mathrm{P}$ : EW at puberty, AEW ${ }^{H}$ : AEW at $345-375$ days of age

Table 3: Least mean squares test of observed genotypes in Mazandaran native breeder hens.

\begin{tabular}{|c|c|c|c|c|c|c|c|}
\hline \multirow{2}{*}{ Trait } & \multicolumn{6}{|c|}{ GH genotypes } & \multirow{2}{*}{ p-value } \\
\hline & AA & $A B$ & AC & BB & BC & CC & \\
\hline BW1 & $35.75 \pm 0.52^{\mathrm{ab}}$ & $35.16 \pm 0.67^{\mathrm{ab}}$ & $36.35 \pm 0.29^{a}$ & $32.36 \pm 1.85^{b}$ & $36.48 \pm 0.48^{a}$ & $35.62 \pm 0.28^{\mathrm{ab}}$ & $0.2027^{\mathrm{ns}}$ \\
\hline BW2 & $1885.35 \pm 32.10^{\mathrm{ab}}$ & $1870.58 \pm 41.34^{\mathrm{ab}}$ & $1890.59 \pm 18.09^{\mathrm{ab}}$ & $1685.99 \pm 113.28^{b}$ & $1867.35 \pm 29.87^{\mathrm{ab}}$ & $1920.64 \pm 17.61^{\mathrm{a}}$ & $0.3112^{\text {ns }}$ \\
\hline EWP & $41.65 \pm 0.87^{\mathrm{ab}}$ & $41.35 \pm 1.07^{\mathrm{ab}}$ & $38.35 \pm 0.49^{b}$ & $41.88 \pm 3.47^{\mathrm{ab}}$ & $40.57 \pm 0.81^{\mathrm{ab}}$ & $45.42 \pm 0.47^{a}$ & $0.0937^{\text {ns }}$ \\
\hline AEW1 & $51.35 \pm 0.65^{\mathrm{ab}}$ & $50.15 \pm 0.83^{b}$ & $53.45 \pm 0.37^{a}$ & $51.50 \pm 2.28^{\mathrm{ab}}$ & $51.29 \pm 0.61^{\mathrm{ab}}$ & $53.95 \pm 0.36^{a}$ & $0.3741^{\text {ns }}$ \\
\hline ENH & $16 \pm 0.78^{b}$ & $16 \pm 1.08^{b}$ & $17 \pm 0.44^{b}$ & $22 \pm 2.53^{a}$ & $16 \pm 0.76^{b}$ & $17 \pm 0.43^{b}$ & $0.1479^{\text {ns }}$ \\
\hline AEW2 & $59.17 \pm 0.74^{a}$ & $56.10 \pm 1.02^{\mathrm{b}}$ & $58.65 \pm 0.42^{\mathrm{a}}$ & $57.49 \pm 2.41^{\mathrm{ab}}$ & $57.56 \pm 0.72^{\mathrm{ab}}$ & $58.85 \pm 0.41^{a}$ & $0.1843^{\text {ns }}$ \\
\hline ASM & $151 \pm 2.28^{a}$ & $144 \pm 2.94^{b}$ & $147 \pm 1.28^{\mathrm{ab}}$ & $140 \pm 8.05^{\mathrm{b}}$ & $148 \pm 2.12^{\mathrm{ab}}$ & $149 \pm 1.25^{\mathrm{ab}}$ & $0.1744^{\text {ns }}$ \\
\hline $\mathrm{PF}$ & $65.65 \pm 4.64^{\mathrm{ab}}$ & $58.39 \pm 6.38^{b}$ & $70.19 \pm 2.63^{\mathrm{ab}}$ & $77.91 \pm 14.97^{\mathrm{a}}$ & $74.76 \pm 4.49^{a}$ & $75.26 \pm 2.59^{a}$ & $0.1720^{\text {ns }}$ \\
\hline
\end{tabular}

ns: Non-Significant, BW1: BW at day one, BW2: BW at puberty, AEW1: AEW at 30 weeks of age, AEW2: AEW at 345-375 days of age, EWP: EW at puberty, ENH: EN at 345-375 days of age

Table 4: Least mean squares test of observed genotypes of $\mathrm{GH}$ gene in Mazandaran native breeder hens. 
selection and breeding for growth, reproduction, immunity and metabolism in chickens for optimum performance. Integrating the relative information with comparative omics (encompassing genomics, transcriptomics, proteomics, and metabolomics), physiological functions, mapping and fine mapping of QTL, signaling pathways and gene networks, method of the candidate gene approach is becoming considerably economical and effective in detecting candidate QTL genes and quantitative trait nucleotides with significant effects on economically important traits [29]. Accordingly, these four growthcorrelated genes were selected and used to analyze the association between polymorphisms with productive and reproductive traits of Mazandaran native breeder fowls.

The association between the polymorphism of GH gene in intron 1 and productive traits of White Leghorn strains was investigated and two alleles of $A_{1}$ and $A_{5}$ and three genotypes of $A_{1} A_{1}, A_{1} A_{5}$ and $A_{5} A_{5}$ were observed. Also, significant correlations were found between SNP with the age of sexual maturity $(\mathrm{P}<0.04)$ and the number of eggs produced from 274 to $385(\mathrm{P}<0.04)$ and from 386 to 497 days of age $(\mathrm{P}<0.01)$ [30]. In the present work research, however, six genotypes of $\mathrm{AA}, \mathrm{BB}, \mathrm{CC}$, $A B, A C$ and $B C$ were observed with different frequencies in intron 1 of $\mathrm{GH}$ gene. In $\mathrm{BW}$ related traits, the mean of $\mathrm{AC}, \mathrm{BC}$ and $\mathrm{CC}$ genotypes were higher than other genotypes and $\mathrm{BB}$ genotype had the lowest record that could be due to the effective $C$ allele. For ASM trait, AA genotype and for EN trait, BB genotype had the highest performances and the difference between genotypes was significant in these traits. The polymorphism of the intron 1 of $\mathrm{GH}$ gene was investigated in several Chinese native chicken breeds, where Yellow Wai Chow breed allelic frequency differed from other breeds, which was similar to the pattern of allelic frequency in Mazandaran native fowls [27]. In this Chinese breed, the frequencies of $\mathrm{A}, \mathrm{B}$ and $\mathrm{C}$ alleles were estimated to be $0.375,0.125$ and 0.500 , respectively, compared to $0.305,0.098$ and 0.597 in Mazandaran native fowls, indicating the similarity of the genetic structure of these two native species. Polymorphism of GH gene and its association with egg production traits in Kadaknath breed was studied and only two alleles of A and C and three genotypes of AA, $A C$ and $C C$ were found, but $B$ allele and expected genotypes entailing $\mathrm{BB}, \mathrm{AB}$ and $\mathrm{BC}$ were not observed in this population, which might have been because of a small number of samples [31]. On the other hand, in addition to the differences in the presence of $B$ alleles and its expected genotypes in comparison with Mazandaran native fowls, the length of the fragments obtained from RFLP in these three genotypes was discordant with the results obtained in Mazandaran native fowls which could be due to the change in the cutting site of the restriction enzyme as a result of mutations in the study of these researchers. Also, in their research, no significant correlation was observed between genotypes and egg number trait, but the mean of AA genotype was significantly lower than other genotypes. Analysis of GH gene SNPs and its association with different production traits in indigenous Hindi chickens and White Leghorn strains indicated that there was no significant relationship between SNPs and average body weight, age of sexual maturity and egg number traits in these two breeds but the differences between mean genotypes for these traits were shown to be significant in both breeds $(\mathrm{P}<0.05)[32]$. Researchers also detected only three genotypes of $\mathrm{AA}, \mathrm{AB}$ and $\mathrm{AC}$ for GH gene in Poltava Clay native chickens, while the effect of SNP on egg number and egg weight traits was not significant, which could probably due to the lack of other genotypes in this population [33]. However, in present study, except for BW at 8 and 12 weeks of age traits, significant differences were found between genotypes in other traits $(\mathrm{P}<0.05)$.

The polymorphism of GHR gene and some productive traits of
White Leghorn strains encompassing body weight at day 140, age at first laying, egg number, specific gravity of egg and egg weight at 240 and 450 days of age was assessed and two haploid genotypes of $\mathrm{H}+$ and $\mathrm{H}$ - were detected with the frequency of 0.55 and 0.45 , respectively, with which no significant association was observed between SNP and these traits [30]. The effect of the polymorphism in intron 5 of GHR gene on some economical traits including egg number, number of doubleyolk eggs and age of sexual maturity in a generation of broiler chickens was studied and two alleles and haploid genotypes of $\mathrm{B}+$ and $\mathrm{B}$ - were detected with the frequency of 0.68 and 0.32 , respectively, however, there was no significant correlation between GHR genotypes and these traits [34]. Researchers also investigated the association between the polymorphisms in introns 2 and 5 of GHR gene and some productive traits of Chinese Wenchang chicken breed entailing egg number, average days of continual egg-laying and number of double-yolk eggs, in which two alleles and haploid genotypes of $\mathrm{B}+$ and $\mathrm{B}$ - were obtained and estimated to be 0.80 and 0.20 , respectively, which was almost the same as the results of present study in Mazandaran native fowls. A significant effect was observed from GHR genotypes in intron 2 on the number of double-yolk eggs as well as an additive effect from this region in this trait $(\mathrm{P}<0.05)[11]$. Although these researchers also did not report any significant association between GHR gene genotypes in intron 5 and egg quality traits including average egg weight and egg shell quality in another study in this population, a significant association was found between GHR genotypes in intron 5 and egg shell thickness and also an additive effect from this region in this trait $(\mathrm{P}<0.05)$ [12]. In a similar study on native fowls of Azerbaijan, two genotypes of $\mathrm{AA}$ and $\mathrm{BB}$ were identified in GHR gene and there was no significant association between genotypes and body weight at 12 weeks of age, age of sexual maturity, average egg weight and egg number traits in this population [35]. Considering the findings of Li et al. in the present study, the effect of GHR genotypes on EN at 345-375 days of age was also observed to be significant $(\mathrm{P}<0.05)$.

The IGF-I gene polymorphism with body weight and egg production traits was investigated in Leghorn chickens. According to genotyping analysis in leghorn chickens, three genotypes of Pst I (-/-), Pst $\mathrm{I}(+/-)$ and PstI (+/+) were detected, where significant associations were found between Pst $\mathrm{I}(-/-)$ genotype and egg weight, egg number and body weight, $P s t \mathrm{I}(+/-)$ genotype with the weight of egg white and PstI $(+/+)$ genotype with feed intake and egg weight $(\mathrm{P}<0.05)$ [17]. In another study, researchers examined the polymorphism of IGF-I gene in chickens and observed polymorphisms included IGFI-SNP1, IGFISNP2, IGFI-SNP3 and IGFI-SNP4 with a significant association that was found between IGFI-SNP1 and average body weight at day 107 and food efficiency at 44, 73 and 107 days of age $(\mathrm{P}<0.05)$ [36]. Furthermore, significant correlations were obtained between IGF-I gene genotypes and body weight at 2, 4, 6, 8 weeks of age and daily body weight gain at weeks $0-2,2-4$ and $4-6$ in chickens $(\mathrm{P}<0.05)$ [37]. In a study on Ogol native chickens, three genotypes of $\mathrm{AA}, \mathrm{AB}$ and $\mathrm{BB}$ were observed for IGF-I gene and the effect of genotypes on average egg weight and egg number traits was significant, where AA genotypes had better performance in egg production than other genotypes [28]. Researchers also observed three genotypes of $\mathrm{BB}(0.32), \mathrm{Bb}(0.41)$ and $\mathrm{bb}(0.27)$ in 5 UTR region of IGF-I gene in Chinese Wenchang chickens and reported a significant association between this SNP and total egg production at 300 and 400 days of age as well as average days of continual egg-laying $(\mathrm{P}<0.05)$ [38]. Another study revealed significant correlations between polymorphisms of IGF-I gene and growth traits including body weight at 2, 4 and 6 weeks of age and average daily weight gain from 0-6 weeks of age in Vietnam's native chickens $(\mathrm{P}<0.05)$ [2]. Investigating the association between the polymorphism of IGF-I gene and some 
productive traits in Mazandaran native fowls population demonstrated a significant effect of this gene on egg number at the first 12 weeks after the flock's sexual maturity [18]. In the present study in Mazandaran native fowls, two alleles of $\mathrm{B}$ and $\mathrm{b}$ and three genotypes of $\mathrm{BB}, \mathrm{Bb}$ and bb were detected with different frequencies. The effects of SNP detected in this gene on EN at 120-270 and 345-375 days of age, EW at puberty and also $\mathrm{PH}$ were shown to be significant $(\mathrm{P}<0.05)$. Additionally, mean comparisons analysis for egg production related traits revealed significant differences between genotypes $(\mathrm{P}<0.05)$, and consequently it was found that homozygous bb genotypes, according to the Kim's report had better performance than other genotypes in egg production, whereas for EW related traits, Bb genotypes had higher records.

A SNP resulting from $\mathrm{C} \rightarrow \mathrm{T}$ transformation in intron 2 of chicken IGFBPII gene was reported to be significantly associated with body weight at the time of hatch and at 7, 14, 21 and 28 days of age $(\mathrm{P}<0.05)$ [22]. In commercial broiler lines, a significant correlation was found between IGFBPII gene SNP in intron 2 with growth traits and carcass compositions [25]. Researchers also reported significant effects of IGFBPII gene on the percentage of drumstick weight and percentage of carcass weight in Arian broiler lines $(\mathrm{P}<0.01)$ [39]. In Chinese native chickens, however, significant associations were found between IGFBPII gene SNPs with abdominal fat weight and percentage of abdominal fat traits $(\mathrm{P}<0.01)$ [26]. The effect of IGFBPII gene polymorphism in intron 2 on the growth rate of Kampung indigenous chickens was analyzed and three genotypes of CC, CT and TT were observed that the genotypic frequency of CT was higher than other genotypes and the allelic effect of $\mathrm{C}$ allele was greater than $\mathrm{T}$ allele and significant correlations were obtained with growth rate at 8-4 and 8-12 weeks of age $(\mathrm{P}<0.05)$ [23]. Investigation the polymorphism of IGFBPII gene in introns 1 and 3 with body weight and reproductive traits in four Chinese native chicken breeds revealed significant correlations between genotypes and body weight at the time of hatch and egg weight at day 300 in Jinghai Yellow breed [40]. In another study carried out by these researchers, intron 2 region of IGFBPII gene was studied in this population and three genotypes of $\mathrm{AA}, \mathrm{AB}$ and $\mathrm{BB}$ (equivalent to $\mathrm{CC}$, $\mathrm{CT}$ and TT in the Mazandaran native fowls population) were detected and no significant correlation was found between genotypes and body weight at 4, 8, 12 and 16 weeks of age. Also, mean comparisons analysis indicated that AA genotypes had higher body weight at 12 weeks of age than other genotypes and it was concluded that the A allele had a positive effect on body weight [24]. In the present study, three genotypes of CC, CT and TT were found with the frequency of 0.14 , 0.62 and 0.24 , respectively, in Mazandaran native fowls population, and the genotypic frequency of CT was significantly higher than the other two genotypes. In addition, for BW at 12 weeks of age trait, CC genotypes showed higher BW, which was consistent with the results of Zhao's studies. Association analysis between polymorphism and traits revealed a significant correlation with AEW at 345-375 days of age $(\mathrm{P}<0.05)$ and for LI trait, the difference between genotypes was indicated to be significant.

\section{Conclusion}

The association between SNPs in GH, GHR, IGF-I and IGFBPII loci and some productive and reproductive traits in Mazandaran native fowls population were studied. Significant correlations were found between these SNPs in GHR gene with EN at 345-375 days of age, in IGF-I gene with EN at 120-270 and 345-375 days of age, EW at puberty, and $\mathrm{PH}$ and in IGFBPII gene with AEW at 345-375 days of age $(\mathrm{P}<0.05)$. Consequently, growth axis genes not only affected productive traits of Mazandaran native fowls, but also were significantly associated with some reproductive traits. Therefore, the polymorphisms of these candidate genes and their associations with these traits can be used as the effective genetic makers to improve Mazandaran native fowls breeding programs in order to enhance production and reproduction performances of this native population.

\section{Conflict of Interest}

All authors have declared no conflict of interest. This study has no conflict of interest.

\section{References}

1. Gao Y, Zhang R, Hu X, Li N (2007) Application of genomic technologies to the improvement of meat quality of farm animals. Meat Science 77: 36-45.

2. Anh NTL, Kunhareang S, Duangjinda M (2015) Association of chicken growth hormones and insulin-like growth factor gene polymorphisms with growth performance and carcass traits in Thai broilers. Asian-Australasian journal of animal sciences 28: 1686.

3. Feng X, Kuhnlein U, Fairfull R, Aggrey S, Yao J, et al. (1998) A genetic marker in the growth hormone receptor gene associated with body weight in chickens. The Journal of Heredity 89: 355-359.

4. Lechniak D, Machnik G, Szydlowski M, Switonski M (1999) Growth hormone gene polymorphism and reproductive performance of Al bulls. Theriogenology 52: $1145-1152$.

5. Donoghue DJ, Campbell RM, Scanes CG (1990) Research note: Effect of biosynthetic chicken growth hormone on egg production in white leghorn hens. Poultry science 69: 1818-1821.

6. Ghelghachi AA, Seyedabadi H, Lak A (2013) Association of growth hormone gene polymorphism with growth and fatness traits in Arian broilers. International Journal of Biosciences 3: 216-220.

7. Aminafshar M, Fathi R (2012) Single nucleotide polymorphisms in intron 1 of growth hormone gene and it's association with economic important traits in Iranian Fars native fowl. Annals of Biological Research 3: 4028-4032.

8. Al-khatib BG, Al-Hassani DH (2016) Effect of G1705A SNP in Growth Hormone Gene on the Productive and Physiological Performance in Broiler Chicken. Iraqi Journal of Biotechnology 15: 33-45.

9. Hull K, Marsh J, Harvey S (1999) A missense mutation in the GHR gene of Cornell sex-linked dwarf chickens does not abolish serum $\mathrm{GH}$ binding. Journal of endocrinology 161: 495-501.

10. Monget $P$, Fabre S, Mulsant $P$, Lecerf F, Elsen JM, et al. (2002) Regulation of ovarian folliculogenesis by IGF and BMP system in domestic animals. Domestic Animal Endocrinology 23: 139-154.

11. Li HF, Zhu WQ, Chen KW, Wu X, Tang QP, et al. (2008) Associations between GHR and IGF-1 gene polymorphisms, and reproductive traits in Wenchang chickens. Turkish Journal of Veterinary and Animal Sciences 32: 281-285.

12. Li H, Zhu W, Chen K, Song W, Shu J, et al. (2010) Effects of the polymorphisms of GHR gene and IGF-1 gene on egg quality in Wenchang chicken. Res J Poult Sci 3: 19-22.

13. Attarchi H, Tahmoorespur M, Ahani Azari M, Sekhavati M, Mohajer M (2017) Allelic polymorphism of GH, GHR and IGF-I genes and their association with growth and carcass traits in Mazandaran native fowl. Poultry Science Journal 5: 25-30.

14. Ouyang J, Xie L, Nie Q, Luo C, Liang Y, et al. (2008) Single nucleotide polymorphism (SNP) at the GHR gene and its associations with chicken growth and fat deposition traits. British poultry science 49: 87-95

15. Miller S, Dykes D, Polesky H (1988) A simple salting out procedure for extracting DNA from human nucleated cells. Nucleic Acids Research 16: 1215

16. Florini JR, Ewton DZ, Coolican SA (1996) Growth hormone and the insulin-like growth factor system in myogenesis. Endocrine reviews 17: 481-517.

17. Nagarajs S, Aggrey S, Yao J, Zadworny D, Fairfull R, et al. (2000) Trait association of a genetic marker near the IGF- I gene in egg laying chicken. $J$ Hered 91: 150-156.

18. Khadem A, Hafezian H, Rahimi-Mianji G (2010) Association of single nucleotide polymorphisms in IGFI, IGF-II and IGFBP-II with production traits in breeder hens of Mazandaran native fowls breeding station. African journal of Biotechnology 9: 805-810. 
Citation: Kazemi H, Rezaei M, Hafezian H, Mianji GR, Najafi M (2018) Genetic Analysis of SNPs in GH, GHR, IGF-I and IGFBPII Genes and their Association with Some Productive and Reproductive Traits in Native Breeder Hens. Gene Technol 7: 145. doi: 10.4172/2329-6682.1000145

19. Musa AA, Orunmuyi M, Akpa GN, Olutunmogun AK, Afolabi-Balogun NB (2016) Effects of insulin-like growth factor I (IGF-I) polymorphism on bodyweight of Nigerian indigenous chickens. African Journal of Agricultural Research 11 1194-1198.

20. Sato S, Ohtake T, Uemoto Y, Okumura Y, Kobayashi E (2012) Polymorphism of insulin-like growth factor 1 gene is associated with breast muscle yields in chickens. Animal Science Journal 83: 1-6.

21. Boschiero C, Jorge EC, Ninov K, Nones K, do Rosário MF, et al. (2013) Association of IGF1 and KDM5A polymorphisms with performance, fatness and carcass traits in chickens. Journal of Applied Genetics 54: 103-112.

22. Lei M, Nie Q, Peng X, Zhang D, Zhang X (2005) Single nucleotide polymorphisms of the chicken insulin-like factor binding protein 2 gene associated with chicken growth and carcass traits. Poultry science 84: 1191-1198.

23. Sidadolog J, Artama W, Maharani D (2013) The Effect of Insulin like Growth Factor Binding Protein 2 Gene on Kampung Chicken Growth Rate. International Journal of Poultry Science 12: 495.

24. Zhao X, Li M, Xu S, Liu G (2015) Single nucleotide polymorphisms in IGFBP-2 gene and their associations with body weight traits on jinghai yellow chicken. Revista Brasileira de Ciência Avícola 17: 497-502.

25. Li Z, Li H, Zhang H, Wang S, Wang Q, et al. (2006) Identification of a single nucleotide polymorphism of the insulin-like growth factor binding protein 2 gene and its association with growth and body composition traits in the chicken. Journal of animal science 84: 2902-2906.

26. Leng L, Wang S, Li Z, Wang Q, Li H (2009) A polymorphism in the 3'-flanking region of insulin-like growth factor binding protein 2 gene associated with abdominal fat in chickens. Poultry science 88: 938-942.

27. Ip SC, Zhang X, Leung FC (2001) Genomic growth hormone gene polymorphisms in native Chinese chickens. Experimental Biology and Medicine 226: 458-462.

28. Kim M, Seo D, Ko Y (2004) Relationship between egg productivity and insulinlike growth factor-I genotypes in Korean native Ogol chickens. Poultry Science 83: 1203-1208.

29. Kuhn M, Von Mering C, Campillos M, Jensen LJ, Bork P (2007) STITCH: interaction networks of chemicals and proteins. Nucleic acids research 36 D684-D688.

30. Feng X, Kuhnlein U, Aggrey S, Gavora J, Zadworny D (1997) Trait association of genetic markers in the growth hormone and the growth hormone receptor gene in a White Leghorn strain. Poultry science 76: 1770-1775.

31. Thakur M, Parmar S, Chaudhari M, Bhardwaj J (2009) Growth hormone gene polymorphism and its association with egg production in Kadaknath chicken Livestock Research for Rural Development 21: 8.

32. Shahnaz S, Shadma F, Rank D, Khannaand K, Joshi C (2008) Growth hormone gene polymorphism and its correlation with different traits in Bantam and White Leghorn chicken. Indian Journal of Poultry Science 43: 23-127.

33. Kulibaba R, Yurko P, Liashenko Y (2015) Mspl-polymorphism in fourth intron of the growth hormone gene in chicken populations of different breeds: Analysis of the causes of additional restriction pattern origin. Cytology and genetics 49 : 372-377.

34. Dunn I, Miao Y-W, Morris A, Romanov MN (2004) A study of association between genetic markers in candidate genes and reproductive traits in one generation of a commercial broiler breeder hen population. Heredity 92: 128

35. Seyyedbabayi M, Seyedabadi H, Gorbani A, Zarghami N (2014) Growth hormone receptor gene polymorphism and its associations with some growth traits in West-Azarbaijan native chicken. Bull Env Pharmacol Life Sci 3: 140-143.

36. Amills M, Jimenez N, Villalba D, Tor M, Molina E, et al. (2003) Identification of three single nucleotide polymorphisms in the chicken insulin-like growth factor 1 and 2 genes and their associations with growth and feeding traits. Poultry science 82: 1485-1493.

37. Zhou H, Mitchell A, McMurtry J, Ashwell C, Lamont SJ (2005) Insulin-like growth factor-I gene polymorphism associations with growth, body composition skeleton integrity, and metabolic traits in chickens. Poultry science $84: 212-219$.

38. Li H, Zhu W, Chen K, Wu X, Tang Q, et al. (2009) Polymorphism in NPY and IGF-I genes associate with reproductive traits in Wenchang chicken. African Journal of Biotechnology 8: 19 .

39. Aliabad JA, Amirinia C, Kamali M, Vaez Torshizi $R$, Seyedabadi $H$, et al. (2010) Polymorphisms of TGF-â3, IGF1 and IGFBP2 genes among Arian broiler chickens and its association with growth and carcass traits. Internationa Information System for the Agricultural Science and Technology.

40. Zhao XH, Wang JY, Zhang GX, Wei Y, Yu YB (2011) Polymorphisms of two neuroendocrine-correlated genes associated with body weight and reproductive traits in Jinghai yellow chicken. African Journal of Biotechnology 10: 11124-11129. 